[RADIOCARBON, VOL. 15, No. 2, 1973, P. 382-387]

\title{
UNIVERSITY OF ROME CARBON-14 DATES XI
}

\author{
M. ALESSIO, F. BELLA, S. IMPROTA
}

Istituto di Fisica, Università di Roma

\section{G. BELLUOMINI, C. CORTESI, and G. L. MANELLI \\ Istituto di Geochimica, Università di Roma}

During the last few years, we have set up the benzene scintillation method in our laboratory. $\mathrm{C}^{14}$ activity measurements are now carried out with both liquid scintillation and $\mathrm{CO}_{2}$-proportional counters. Chemical apparatus for benzene synthesis and a liquid scintillation spectrometer for low-level counting were built and are described below.

After standard pretreatment, carbon is converted to $\mathrm{CO}_{2}$ by combustion or acid treatment and then synthesized to liquid benzene in a closed system for ca. 8 hours. The combustion line was set up after Broecker et al. (1959), connected with a benzene synthesizing line designed as suggested by Noakes et al. (1963; 1965; 1967), as well as with new designs and operating features (Alessio et al., 1970b).

Converting a sample to $\mathrm{CO}_{2}$ requires 90 to $120 \mathrm{~min}$., yielding from $95 \%$ to $98 \% \mathrm{CO}_{2}$. For the conversion of $\mathrm{CO}_{2}$ into $\mathrm{C}_{6} \mathrm{H}_{6}$, Table 1 shows reactions, time, and yields.

TABLE 1

Benzene synthesis

\begin{tabular}{|c|c|c|}
\hline Reactions & Yields $(\%)$ & Time (min.) \\
\hline a) $\left\{\begin{array}{l}2 \mathrm{CO}_{2}+10 \mathrm{Li} \longrightarrow \mathrm{Li}_{2} \mathrm{C}_{2}+4 \mathrm{Li}_{2} \mathrm{O} \\
2 \mathrm{C}+2 \mathrm{Li} \longrightarrow \mathrm{Li}_{2} \mathrm{C}_{2}\end{array}\right.$ & & $60-90$ \\
\hline b) $\mathrm{Li}_{2} \mathrm{C}_{22}+\underset{\text { catalyst }}{2 \mathrm{H}_{2} \mathrm{O}} \longrightarrow \mathrm{C}_{2 .} \mathrm{H}_{2}+2 \mathrm{LiOH}$ & $98-100$ & $20-30$ \\
\hline c) $3 \mathrm{C}_{2} \mathrm{H}_{2} \longrightarrow \mathrm{C}_{6} \mathrm{H}_{6}$ & $98-100$ & $180-240$ \\
\hline
\end{tabular}

a) In synthesis of $\mathrm{Li}_{2} \mathrm{C}_{2}$ metallic lithium pellets are used, in $10 \%$ $>$ stoichiometrically required quantity. The metal is slowly brought to melting (ca. $600^{\circ} \mathrm{C}$ ), completed in $15-20$ min.; subsequently the tcmpcrature rises to ca. $800^{\circ} \mathrm{C}$ and lithium assumes an orange-red color. It was found that, kecping the temperature at ca. $800^{\circ} \mathrm{C}$ for $>15-20$ min. after the total disappearance of $\mathrm{CO}_{2}$, the $\mathrm{C}_{6} \mathrm{H}_{6}$ yield is further raised to ca. 95\% (Polach and Stipp, 1967).

Reaction completed, all traces of radon are removed by keeping the reactor bottom under vacuum at $\mathrm{ca} .600^{\circ} \mathrm{C}$ for $30 \mathrm{~min}$. The lithium carbide synthesis reaction is quantitative and fairly fast: not $>90 \mathrm{~min}$. is required to convert $10 \mathrm{~L} \mathrm{CO}$.

b) Distilled water is made to flow at ca. $200 \mathrm{ml} / \mathrm{min}$. over lithium carbide at room temperature, at the same time cooling the bottom of reaction chamber, reaction being exothermic. Acetylene is frozen in 
liquid nitrogen; water vapor, ammonia compounds, and hydrogen are suitably removed.

c) For trimerization of acetylene to benzene, a catalyst developed by Noakes et al. (1967) was used initially, consisting of $20 \% \mathrm{~V}_{2} \mathrm{O}_{5}$ on a silica-alumina support with a minimum specific surface of $200 \mathrm{~m}^{2} / \mathrm{g}$. Immediatcly before use, the catalyst was activated at ca. $300^{\circ} \mathrm{C}$ under rotary pump vacuum for 2 hours, while cycling reaction was carried out at $13 \pm 1{ }^{\circ} \mathrm{C}$, for at this temperature reaction kinetics were faster (Alessio et al., 1970b). This catalyst could be reactivated several times by heating to ca. $300^{\circ} \mathrm{C}$ under vacuum for 2 hours, with yields always $>90 \%$ and high reaction kinetics.

At present our laboratory uses the KC-Perlkatalysator Neu catalyst, Kaly-Chemie A. G., Hamnover. This product is activated to ca. $350^{\circ} \mathrm{C}$ for $15-20 \mathrm{~min}$, while the temperature of acetylene to benzene trimerization begins at $\mathrm{ca} .50^{\circ} \mathrm{C}$, allowing reaction to proceed spontaneously. It was found that $\log \mathrm{g}$ of this non-regenerative catalyst is sufficient to produce up to $5.5 \mathrm{ml}$ benzene and all gas-chromatographic analyses of samples have always shown a degree of purity from 99.5 to $100 \%$.

In a pyrex counting vial $4.5 \mathrm{ml}$ liquid is introduced, containing $2 \mathrm{ml}$ sample benzene and $2.5 \mathrm{ml} \mathrm{NE} 216$ liquid scintillator produced by Nuclear Enterprises Lul. The cylindrical vial, ca. $1 / 3$ as high as its diam., is inserted coaxially into a light pipe, to the ends of which are connected 2 photomultipliers operating in coincidence.

An anti-coincidence shicld is formed by a plastic scintillator enclosing a light pipe and connected with a 3rd photomultiplier operating in anti-coincidence with the first two. The scintillation spectrometer is in a room at $18^{\circ} \mathrm{C}$ and is protected against soft component of cosmic radiation by a $20 \mathrm{~cm}$ iron and $15 \mathrm{~cm}$ lead shield. Data are recorded by an electronic unit incorporating coincidence circuits with 7 ns resolution timcs. Each activity measurement lasts ca. 24 hours, with regularity checks at 30 -min. intervals. Background is $6.47 \pm 0.04 \mathrm{cpm}$, the net modern activity $13.43 \pm 0.08 \mathrm{cpm}$, and the figure of merit $\mathrm{E}^{2} / \mathrm{B}=580$.

This list includes age measurements of check samples and of now series of Italian geologic and historic samples made by the liquid scintillation method.

As in clating with $\mathrm{CO}_{2}$-proportional counters in preceding lists, "modern standard" is wood grown near Rome from 1949 to 1953, whose activity was repeatedly checked with $95 \%$ of the activity of NBS oxalic acid. Errors quoted are $l_{\sigma}$ statistical error. Ages were calculated using the Libby latf-life of $5568 \mathrm{yr}$, with 1950 as the standard year of reference.

\section{ACKNOWLEDGMENTS}

We wish to thank the Consiglio Nazionale delle Ricerche for providing partial financial support. We also thank our technicians for their devotion and skill in developing the chemical equipment: $A$. Pellizzoni, M. Dante, and L. Lucidi for mechanics and $O$. Fogì for glassblowing. 


\section{SAMPLE DESCRIPTIONS}

I. CHECK SAMPLES

The liquid scintillation method was checked, using for benzene synthesis $\mathrm{CO}_{2}$ obtained from various samples dated with the proportional counter. Ages obtained from both methods agree satisfactorily and are compared in Table 2.

TABLE 2

Check samples

\begin{tabular}{|c|c|c|c|}
\hline Sample & $\begin{array}{c}\mathrm{C}^{14} \text { age liquid } \\
\text { scintillation } \\
\text { method }\end{array}$ & $\begin{array}{c}\mathrm{C}^{1+1} \text { age } \mathrm{CO}_{2^{-}} \\
\text {proportional } \\
\text { counting method }\end{array}$ & References \\
\hline $\mathrm{R}-716$ & $28,500 \pm 2000$ & $27,800 \pm 800$ & R., 1971, v. 13, p. 404 \\
\hline $\mathrm{R}-578$ & $12,650 \pm 250$ & $11,820 \pm 120$ & R., 1971 , v. 13 , p. 406 \\
\hline $\mathrm{R}-703$ & $5000 \pm 70$ & $4360 \pm 50$ & R., 1971, v. 13, p. 407 \\
\hline R-706 & $11,500 \pm 200$ & $11,800 \pm 100$ & R., 1971, v. 13, p. 407 \\
\hline $\mathrm{R}-594$ & $8480 \pm 200$ & $8400 \pm 70$ & R., 1971, v. 13, p. 409 \\
\hline $\mathrm{R}-595$ & $5850 \pm 160$ & $5880 \pm 50$ & R., 1971, v. 13, p. 409 \\
\hline $\mathrm{R}-375$ & $3230 \pm 100$ & $3360 \pm 50$ & R., 1973, v. 15, p. 165 \\
\hline $\mathrm{R}-375 \alpha$ & $3840 \pm 80$ & $3160 \pm 50$ & R., 1973, v. 15, p. 165 \\
\hline $\mathrm{R}-831 \mathrm{~A} \alpha$ & $1730 \pm 90$ & $1710 \pm 50$ & R., 1973, v. 15, p. 169 \\
\hline $\mathrm{R}-834 \alpha$ & $1650 \pm 90$ & $1700 \pm 50$ & R., 1973, v. 15, p. 169 \\
\hline $\mathrm{R}-836 \alpha$ & $1760 \pm 100$ & $1680 \pm 50$ & R., 1973, v. 15, p. 169 \\
\hline R-823 & $16,400 \pm 400$ & $16,390 \pm 180$ & R., 1973 , v. 15, p. 175 \\
\hline $\mathrm{R}-825$ & $15,900 \pm 300$ & $15,090 \pm 140$ & R., 1973, v. 15, p. 173 \\
\hline R -707 & $3600 \pm 90$ & $3650 \pm 50$ & R., 1973 , v. 15, p. 175 \\
\hline
\end{tabular}

IJ. GEOLOGIC SAMPLES

Italy

\section{R-241. Ghiacciaio del Rutor}

\section{R-241 $\alpha$. Ghiacciaio del Rutor}

$5950 \pm 130$

4000 B.c.

Brown-blackish peat with leaf remains (Cyperaceae, Bryophyta), and detritus with no wood, in terminal moraine of $\mathrm{W}$ branch of Rutor Glacier near confluence with $\mathrm{E}$ branch, $250 \mathrm{~m}$ S Rutor Lake, Upper Valley Dora di la Thuile R., Valle d'Aosta, Piedmont (45 $39^{\circ} 53^{\prime \prime} \mathrm{N}$ Lat, $6^{\circ} 57^{\prime} 24^{\prime \prime}$ E Long) at $+2515 \mathrm{~m}$; coordinate system U.T.M. 32 TLR 42905910. Coll. 1958 by L. Peretti, and subm. 1966 by G. Charrier, both of Ist. Giacim. Min., Politecnico Turin. Peat is believed to come from an ancient peat bog, later covered and reworked by glacier, at foot of a ligh rocky shelf, at $+2776 \mathrm{~m}$. Peat therefore provides evidence of a Rutor glacier terminal margin a few hundred $\mathrm{m}$ behind present one and glaciated area diminished $>2 \mathrm{~km}^{2}$, corresponding to a major Holo- 
cene anathermic phase (Peretti, 1964). Pollen analysis of peat shows: Pinus, several species, $(57.45 \%)$, Abies $(34.44 \%)$, Tilia $(2.75 \%)$ (Charrier, 1964). Comment: R-24l was pretreated with $10 \% \mathrm{HCl}$; R-241 $\alpha$ was given additional leaching with $6 \% \quad \mathrm{NH}_{4} \mathrm{OH} . \mathrm{R}-241_{\alpha}$ date, indicating the climax of postglacial climatic optimum (Atlantic), substantially agrees well with pollen analysis showing predominance of Abies assoc. with Pinus and with characteristic mixed forest components (Tilia). Radiometric data, therefore, rule out other controversial reference to anathermic climatic phases of Late Holocene (Sub-Atlantic).

Other peat bogs and lacustrine deposits dated in various areas of the Alps to establish a chronology of postglacial climatic events (see: R., 1964 , v. 6 , p. $85-87$; 1968, v. 10 , p. $359-360$; v. 12 , p. $610-611)$.

\section{Lago di Tenno series}

Well-preserved trunks in situ on bottom of Tenno Lake, $4.5 \mathrm{~km}$ $\mathrm{N}$ Tenno, prov. Trento, Trentino (45 $56^{\prime} \mathrm{N}$ Lat, $10^{\circ} 49^{\prime} \mathrm{E}$ Long) at $+570 \mathrm{~m}$. Coll. 1970 by Gruppo Sommozzatori di Riva del Garda and subm. by B. Bagolini, Mus. Tridentino Sci. Nat., Trento.

Trunks belong to submerged forest covering ca. $1 / 5$ lake bottom on $\mathrm{W}$ side. Over 70 trees have been mapped by Mus. and are being id. by F. Pedrotti, Ist. Bot., Univ. Camerino. Samples dated with and without acid pretreatment (A-labelled samples): no carbonate present.

\section{R-793. Lago di Tenno A}

R-793A. Lago di Tenno A well.

Well-preserved, small trunk in situ. Comment: 2 dates do not agree

$$
1190 \pm 80
$$

\section{A.D. 760}

$790 \pm 70$

$570 \pm 70$

\section{R-794. Lago di Tenno B}

A.D. 1380

\section{R-794A. Lago di Tenno B}

$$
630 \pm 70
$$

Well-preserved, very small trunk or branch in situ. Comment: 2 dates agree.

\section{R-795. Lago di Tenno C28}

$$
\begin{array}{r}
1000 \pm 70 \\
\text { A.D. } 950
\end{array}
$$

\section{R-795A. Lago di Tenno C28}

$$
940 \pm 70
$$

Well-preserved wood, ca. $25 \mathrm{~cm}$ diam. trunk in situ. Comment: 2 dates agree.

General Comment: $\mathrm{C}^{1 *}$ dates, in particular R-794 ages, seem to confirm traditional belief that Tenno Lake basin was formed by a landslide ca. A.D. 1400 (Battisti, 1898; Tomasi, 1963; Untergasser, 1935; Venzo, 1935). 


\section{Pontelagoscuro series}

In 1970, a water prospecting test, $60 \mathrm{~cm}$ diam. and ca. $40 \mathrm{~m}$ deep, was drilled by dry cable-tool method along Natl. Hwy. No. 16 about mid-way between Pontelagoscuro and Ferrara, Emilia (44' 5 $1^{\prime} 58^{\prime \prime} \mathrm{N}$ Lat, $11^{\circ} 36^{\prime} 00^{\prime \prime} \mathrm{E}$ Long) at $+8.50 \mathrm{~m}$. Drill core was preserved for study. Later, at same location, a $3.5 \mathrm{~m}$ diam. and $40 \mathrm{~m}$ deep well was driven to trap aquifers located at deptlis 11 to $36 \mathrm{~m} ; 2$ levels were found, 30.10 and $34.90 \mathrm{~m}$ deep, rich in vegetable remains and 1 level, $35.70 \mathrm{~m}$ deep, with abundant, large wood fragments. Coll. 1970 by drilling staff and subm. 1970 by M. Bondesan, Ist. Geol., Univ. Ferrara.

\section{R-862. Pontelagoscuro 1}

$32,500 \pm 2000$

Vegetable remains, mainly small wood fragments, fairly well-preserved, from coarse sand level, $30.10 \mathrm{~m}$ deep. Comment: sample pretreated with $10 \% \mathrm{HCl}$ only because, despite slight darkening, test with $0.2 \mathrm{~N} \mathrm{NaOH}$ did not disclose humic material.

\section{R-863 $\alpha$. Pontelagoscuro 2}

$35,000 \pm 3000$

Vegetable remains, mainly small darkened wood fragments, found in coarse clayey sand $34.90 \mathrm{~m}$ decp. Comment: sample was pretreated with $10 \% \mathrm{HCl}$ and given additional leaching with $0.2 \mathrm{~N} \mathrm{NaOH}$.

\section{R-864. Pontelagoscuro 3}

$27,500 \pm 1000$

Fragment of well-preserved wood, $35 \mathrm{~cm}$ long and $3 \mathrm{~cm}$ diam., found in coarse clayey sand rich in large wood fragments, $37.70 \mathrm{~m} \mathrm{deep.} \mathrm{Com-}$ ment: sample pretreated with $10 \% \mathrm{HCl}$ only, as alkaline treatment was not considered necessary.

General Comment: as supposed, $\mathrm{C}^{14}$ dates indicate Würm age. However, dates cannot yet be fully interpreted since lithologic and paleontologic study of core has barely started; sedimentary environment and origin of dated materials have not yet been determined. In the area only known stratigraphy is from deep natural-gas prospecting well (Selli, 1945-46).

III. HISTORIC SAMPLES

$$
\text { Italy }
$$

\section{R-913. S. Andrea, Orvieto}

Humic acids from brown earthy layer in archeol. excavations of a sacred area underlying St. Andrea's Church, Orvicto, Umbria. Coll. 1970 by M. P. Rossignani, and subm. 1971 by M. Cagiano de Azcvedo, both of Ist. Archeol., Univ. Cattolica, Milan. Comment: layer containing scarce small bone fragments and charcoal appears as a final fire level indicating last stage of use of a sacred area of Villanovan-Etruscan age with superimposed foundations of a Palaeochristian basilica (Cagiano de Azevedo, 1972). Bones and charcoal being insufficient, humic acids 
of layer judged uncontaminated by more recent carbon were dated; results are merely suggestive although they agree with expected archaeol. age.

\section{REFFRFNCES}

Alessio, M., Bella, F., and Cortesi, C., 1964, University of Rome carbon-14 dates II: Radiocatbon, v. 6, p. 77-90.

Alessio, M., Rella, F., Cortesi, C., atnd Graziadei, B., 1968, University of Rome carbonl4 dates VI: Radiocarbon, v. 10 , p. $350-364$.

Alessio, M., Bella, F., Improta, S., Belluomini, G., Calderoni, G., Cortesi, C., and Turi, B., 1973, University of Rome carbon-14 dates X: Radiocarboll, v. 15, p. $16.5-178$.

Alessio, M., Bella, F., Improta, S., Belluomini, G., Cortesi, C., and Iuri, B., 1970a, Eniversity of Rome carbon-14 dates VIII: Radiocarbon, v. 12 p. 599-616. - 1970b, Report on the equipment and the activities of Rome Lniversitys carbon-14 dating labonatory: Quaternaria, v. 13, p. $357-376$. $395-411$

Battisti, C., 1898, Il Irentino: Trento, Zippel Editore.

Brocker, W. S., Tucek, C. S., and Olson, E., 1959, Radio-carbon analysis of oceanic $\mathrm{CO}_{2}$ : Internatl. Jour. appl. Rad. Isotopes, v. 7, p. 1-18.

Cagiano de Azevedo, M., 1973, Un trionfo e una sconfitia: M. Volconios e Vulsinium: La Parolat del Passato, in press.

Charrier, (;., 1964, Atalisi pollinica della torba recentemente raccolta alla fronte del ghiacciaio del Rutor: Com. Glaceol. Italiano Boll., ser. 2, v. 14, p. 9-19.

Noakes, J. F., Isbell, A. F., Stipp, J. J., and Hood, D, W., 1963, Benzene synthesis by low temperature catalysis for radiocabon dating: Geochim. et Cosmochim. Acta, v. 27, p. $797-804$.

Noakes, J. E., Kim, S. M., and Akers, L. K., 1967, Recent improvements in benzene chemistry for radiocabon dating: Geochim. et Cosmochin. Acta, v. 31, p. 10941096.

Noakes, J. E., Kim, S. M., and Stipp, J. J., 1965, Chemical and connting advances in licuirl scintillation age dating: Gth internatl, conf. radiocarbon and tritium dating Proc., Pullman, Washington, June 7-11, 1965, p. 68-92.

Peretti, L., 1964, Sulla presenza di torba nella morena deposta durante gli ulimi anni alla fronte atuale rlel ghiacciaio occidentale del Rutor: Com. Ciaceol. Italiano Boll., ser. 2, v. 14, p. 1-59.

Polach, I. A. and Stipp, J. J., 1967, Improved synthesis techniques for methane and benzenc radiocanbon dating: Internatl. Jour, appl. Rad. Isotopes, v. 18, p. 359-364.

Selli, R., 1915-46, La stratigrafia di un pozzo profondo perforato presso Pontelagoscuro (Ferrata): Cior. di Cicol., ser. 2, v. I8, p. 53.72

Iomasi, D., 1963, I laghi del Irentino: Rovereto, Manfrini Editore.

Untergasser, S., 1935, Elementi morfometrici del Lago di Tenno: Surdi Trentini sci. Nat, v. 16, p. 144-115.

Venzo, S., 1935, Ricerche limnologiche trentine: il Lago di Tenno-Cenni geograficogeologici: Studi Trentini Sci. Nat., v. 16, p. 133-144. 